\title{
microorganisms
}

ISSN 2076-2607

www.mdpi.com/journal/microorganisms

Review

\section{Alicyclobacillus spp.: New Insights on Ecology and Preserving Food Quality through New Approaches}

\author{
Emanuela Ciuffreda, Antonio Bevilacqua, Milena Sinigaglia and Maria Rosaria Corbo * \\ Department of the Science of Agriculture, Food and Environment, University of Foggia, Via Napoli 15, \\ 71122 Foggia, Italy; E-Mails: emanuela.ciuffreda@unifg.it (E.C.); \\ antonio.bevilacqua@unifg.it (A.B.); milena.sinigaglia@unifg.it (M.S.)
}

* Author to whom correspondence should be addressed; E-Mail: mariarosaria.corbo@unifg.it;

Tel.: +39-08-8158-9232.

Academic Editor: Giuseppe Comi

Received: 27 July 2015 / Accepted: 29 September 2015 / Published: 10 October 2015

\begin{abstract}
Alicyclobacillus spp. includes spore-forming and thermo-acidophilic microorganisms, usually recovered from soil, acidic drinks, orchards and equipment from juice producers. The description of the genus is generally based on the presence of $\omega$-fatty acids in the membrane, although some newly described species do not possess them. The genus includes different species and sub-species, but A. acidoterrestris is generally regarded as the most important spoiler for acidic drinks and juices. The main goal of this review is a focus on the ecology of the genus, mainly on the species A. acidoterrestris, with a special emphasis on the different phenotypic properties and genetic traits, along with the correlation among them and with the primary source of isolation. Finally, the last section of the review reports on some alternative approaches to heat treatments (natural compounds and other chemical treatments) to control and/or reduce the contamination of food by Alicyclobacillus.
\end{abstract}

Keywords: isolation, source, genotyping, phenotyping

\section{Introduction: The General Traits of Alicyclobacillus spp.}

The genus Alicyclobacillus belongs to the family of Alicyclobacillaceae [1], and consists of a group of thermo-acidophilic, strictly aerobic, heterotrophic, and spore-forming bacteria [2,3]. 
First, alicyclobacilli were placed in the genus Bacillus, as they share with bacilli the characteristic of endospore formation. However, phylogenetic analysis based on sequence comparisons of the 16S rRNA showed that the species of the genus Alicyclobacillus belonged to a distinct line of descent within the low G + C (guanine + cytosine) Gram-positive lineage of Bacteria also including the closely related facultatively autotrophic species of Sulfobacillus spp. [2,4,5]. Therefore, in 1992 they were allocated to a new genus called Alicyclobacillus due to the presence of $\omega$-cyclohexyl or $\omega$-cycloheptyl fatty acids as the major natural membrane lipid component [6,7]. These $\omega$-alicyclic fatty acids may be associated with the heat and acid resistance of Alicyclobacillus spp. [8], as they are responsible for the ability to survive typical pasteurization regimes applied during juice manufacturing, since Alicyclobacillus spp. may be present on fruit surfaces contaminated by soil during production and harvesting [9]. In single-strength juice, these microorganisms find a favourable environment for germination, growth, and spoilage [8].

The genus originally consisted of three species, A. acidocaldarius, A. acidoterrestris and A. cycloheptanicus. Nowdays, it consists of 22 species isolated from various habits (Table 1).

Table 1. Phenotypic Characteristics of Alicyclobacillus spp.

\begin{tabular}{|c|c|c|c|c|c|c|c|}
\hline Species & Source of Isolation & $\begin{array}{c}\text { Temp. } \\
\text { Range }\left({ }^{\circ} \mathrm{C}\right)\end{array}$ & $\begin{array}{c}\text { Optimum } \\
\text { Temperature } \\
\left({ }^{\circ} \mathrm{C}\right) \\
\end{array}$ & $\begin{array}{c}\text { pH } \\
\text { Range }\end{array}$ & $\begin{array}{c}\text { Optimum } \\
\text { pH }\end{array}$ & 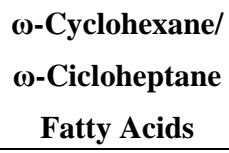 & References \\
\hline A. acidiphilus & acidic beverages & $20-55$ & 50 & $2.5-5.5$ & 3.0 & $\omega$-cyclohexane & {$[10]$} \\
\hline A. acidocaldarius & soil, fruits, syrup & $35-70$ & $55-60$ & $2.5-6.0$ & 4.5 & $\omega$-cyclohexane & {$[2]$} \\
\hline A. acidoterrestris & soil, acidic beverages & $20-55$ & $40-50$ & $2.0-6.0$ & $3.5-4.5$ & $\omega$-cyclohexane & {$[2]$} \\
\hline A. aeris & copper mine & $25-35$ & 30 & $2.0-6.0$ & 3.5 & none & [11] \\
\hline A. cellulosilyticus & cedar chips & $40.0-67.5$ & 55 & $3.5-6.5$ & 4.8 & $\omega$-cyclohexane & [12] \\
\hline A. contaminans & juices & $35-60$ & $50-55$ & $3.0-6.0$ & $4.0-4.5$ & none & {$[13]$} \\
\hline A. cycloheptanicus & soil & $30-55$ & 50 & $3.0-5.5$ & 4.0 & $\omega$-cycloheptane & {$[2]$} \\
\hline A. dauci & spoiled mixed juice & $20-50$ & 40 & $3.0-6.0$ & 4.0 & $\omega$-cyclohexane & [14] \\
\hline A. disulfidooxidans & wastewater sludge & $04-40$ & 35 & $0.5-6.0$ & $1.5-2.5$ & $\omega$-cyclohexane & {$[15]$} \\
\hline A. fastidiosus & soil, beverages & $20-55$ & $40-45$ & $2.0-5.5$ & $4.0-4.5$ & $\omega$-cyclohexane & {$[13]$} \\
\hline A. ferrooxydans & solfataric soil & $17-40$ & 28 & $2.0-6.0$ & 3.0 & none & {$[16]$} \\
\hline A. herbarius & herbal tea & $35-65$ & $55-60$ & $3.5-6.0$ & $4.5-5.0$ & $\omega$-cycloheptane & [17] \\
\hline A. hesperidum & solfataric soil & $35-60$ & $50-53$ & $2.5-5.5$ & $3.5-4.0$ & $\omega$-cyclohexane & [18] \\
\hline A. kakegawensis & soil & $40-60$ & $50-55$ & $3.0-6.5$ & $4.0-4.5$ & $\omega$-cycloheptane & {$[13]$} \\
\hline A. macrosporangiidus & $\begin{array}{c}\text { beverages, } \\
\text { environments }\end{array}$ & $35-60$ & $50-55$ & $3.0-6.5$ & $4.0-4.5$ & none & [13] \\
\hline A. pomorum & fruits & $30-60$ & $45-50$ & $2.5-6.5$ & $4.5-5.0$ & none & [19] \\
\hline A. sacchari & sugar & $30-55$ & $45-50$ & $2.0-6.0$ & $4.0-4.5$ & $\omega$-cyclohexane & [13] \\
\hline A. sendaiensis & soil & $40-65$ & 55 & $2.5-6.5$ & 5.5 & $\omega$-cyclohexane & [20] \\
\hline A. shizuokaensis & soil & $35-60$ & $45-50$ & $3.0-6.5$ & $4.0-4.5$ & $\omega$-cycloheptane & [13] \\
\hline A. tengchongensis & hot spring soil & $30-50$ & 45 & $2.0-6.0$ & 3.2 & $\omega$-cycloheptane & [21] \\
\hline A. tolerans & solfataric soil & $20-55$ & $37-42$ & $1.5-5.0$ & $2.5-2.7$ & $\omega$-cyclohexane & [15] \\
\hline A. vulcanalis & geothermal pool & $35-65$ & 55 & $2.0-6.0$ & 4.0 & $\omega$-cyclohexane & [22] \\
\hline
\end{tabular}

Twelve species of Alicyclobacillus, namely A. acidocaldarius, A. acidoterrestris [2], A. hesperidum [18], A. acidiphilus [10], A. sendaiensis [20], A. disulfidooxidans, A. tolerans [15], A. fastidiosus, 
A. sacchari [13], A. vulcanis [22], A. cellulosilyticus [12], and A. dauci [14], contain $\omega$-cyclohexane fatty acids, whereas A. cycloheptanicus [23], A. kakegawensis, A. shizoukensis [13], A. herbarius [17], and A. tengchongensis [20] contain $\omega$-cycloheptane fatty acids.

Recent studies [24] pinpointed the lack of these fatty acids in A. aeris [20], A. ferrooxydans [16], A. pomorum [19], A. macrosporangiidus and A. contaminans [14]. These species also possess a lot of phenotypic characteristics different from the classical traits of Alicyclobacillus spp., including growth temperature, assimilation of various carbon sources, production of acids from a range of compounds, and the ability to grow chemoautotrophically using ferrous iron, elemental sulphur and tetrathionate as electron donors $[11,13,19]$. However, genotypic analysis showed that they were phylogenetically related to members of the genus Alicyclobacillus [11,13,16,19].

Generally, interest in Alicyclobacillus spp. focused on the study of the role of $\omega$-cyclic fatty acids and hopanoids on membrane function [25,26]. These $\omega$-alicyclic fatty acids could be associated with the strong heat and acid resistance of Alicyclobacillus spp. [8]. Kanneberg et al. [26] demonstrated that lipids, which contain $\omega$-cyclohexane fatty acid, packed densely, resulting in low diffusion at high temperatures. Wisotzkey et al. [2] proposed that this property provided an advantage at high temperatures or low $\mathrm{pH}$. Lipids containing fatty acids with a cyclohexane ring could stabilize the membrane structure and maintain the barrier functions of prokaryotic membranes at high temperatures [26]. These fatty acids might contribute to the heat resistance of Alicyclobacillus by forming a protective coating with strong hydrophobic bonds. These hydrophobic bonds might stabilize and reduce membrane permeability in extreme acidic and-high temperature environments [2,26,27].

However, some authors reported that the presence of $\omega$-cyclohexyl fatty acids is not essential in protecting alicyclobacilli from high temperatures and low $\mathrm{pH}$, because there are other microorganisms, such as Curtobacterium pusillum [28] and Propionibacterium cyclohexanicum [29], that also possess $\omega$-alicyclic acids, and are neither thermophilic nor acidophilic (Propionibacterium cyclohexanicum is an acidotolerant bacterium).

The possible way to justify the adaptation to extreme environments of alicyclobacilli might be the presence of hopanoids in their cells $[7,8,25]$. The hopane glycolipids are structurally similar to cholesterol and have a condensing effect on the cell membrane due to a decrease of the acyl chain lipids' mobility. At low $\mathrm{pH}$ the condensing action hinders the passive diffusion of protons through the membrane, facilitating the establishment of an approximately neutral cytoplasmic $\mathrm{pH}$ [25]. The low membrane viscosity induced by branched-chain fatty acids is thus counterbalanced by the presence of a higher concentration of hopanoids, leading to a more stable membrane.

\section{Characteristic of Alicyclobacillus spp.}

The genus Alicyclobacillus is most closely related to the genus Bacillus and comprises thermophilic-acidophilic spore-forming bacteria. The genome study of this organism was fundamental for its phylogenetic position. In GenBank there are the complete genome sequences of each species. 16S ribosomal RNA (rRNA) sequencing is a common amplicon sequencing method used to identify and compare bacteria present within a given sample. 16S rRNA gene sequencing is a well-established method for studying phylogeny and taxonomy of samples from complex microbiomes or environments that are difficult or impossible to study. 
Wisotzkey et al. [2] proposed that 16S rRNA gene sequences must be at least $92 \%$ similar to belong to the genus Alicyclobacillus. Within closely related species, especially belonging to the A. acidocaldarius group, the similarity is over 98\%. Table 2 reports the similarity level of $16 \mathrm{~S}$ rRNA and G + C content of DNA in Alicyclobacillus spp.

Table 2. Genotypic characteristics of Alicyclobacillus spp.

\begin{tabular}{|c|c|c|c|}
\hline Species & $\begin{array}{l}\text { DNA G + C } \\
\text { Content (\%) }\end{array}$ & $\begin{array}{l}\text { Homology with 16S rRNA of Some Other } \\
\text { Species of the Genus }\end{array}$ & References \\
\hline A. acidiphilus & 54.1 & A. acidoterrestris (96.6\%) & {$[10]$} \\
\hline A. acidocaldarius & 61.89 & A. acidoterrestris (98.8\%) & {$[30]$} \\
\hline A. acidoterrestris & 51.5 & A. acidocaldarius (98.8\%) & {$[2]$} \\
\hline A. aeris & 51.2 & A. ferrooxydans (94.2\%) & {$[11]$} \\
\hline A. cellulosilyticus & 60.8 & A. macrosporangiidus (91.9\%) & {$[12]$} \\
\hline A. contaminans & $61.1-61.6$ & Alicyclobacillus (92.3\%-94.6\%) & {$[13]$} \\
\hline A. cycloheptanicus & 57.2 & Alicyclobacillus (92.7\%-93.2\%) & {$[2]$} \\
\hline A. dauci & 49.6 & $\begin{array}{l}\text { A. acidoterrestris }(97.4 \%) \text { and } A \text {. fastidiosus } \\
\qquad(97.3 \%)\end{array}$ & {$[14]$} \\
\hline A. disulfidooxidans & 53 & A. tolerans $(92.6 \%)$ & [15] \\
\hline A. fastidiosus & 53.9 & Alicyclobacillus (92.3\%-94.6\%) & {$[13]$} \\
\hline A. ferrooxydans & 48.6 & A. pomorum $(94.8 \%)$ & {$[16]$} \\
\hline A. herbarius & 56.2 & $\begin{array}{l}\text { Alicyclobacillus (91.3\%-92.6\%) and } \\
\text { Sulfobacillus thermosulfidooxidans (84.7\%) }\end{array}$ & [17] \\
\hline A. hesperidum & 60.3 & Alicyclobacillus (97.7\%-98\%) & {$[18]$} \\
\hline A. kakegawensis & $61.3-61.7$ & Alicyclobacillus (92.3\%-94.6\%) & {$[13]$} \\
\hline A. macrosporangiidus & 62.5 & Alicyclobacillus (92.3\%-94.6\%) & {$[13]$} \\
\hline A. pomorum & 53.1 & Alicyclobacillus (92.5\%-95.5\%) & [19] \\
\hline A. sacchari & 56.6 & Alicyclobacillus (92.3\%-94.6\%) & {$[13]$} \\
\hline A. sendaiensis & 62.3 & A. vulcanis (96.9\%) & {$[22]$} \\
\hline A. shizuokaensis & 60.5 & Alicyclobacillus (92.3\%-94.6\%) & {$[13]$} \\
\hline A. tengchongensis & 53.7 & Alicyclobacillus (90.3\%-92.8\%) & {$[21]$} \\
\hline A. tolerans & 48.7 & $\begin{array}{l}\text { Alicyclobacillus (92.1\%-94.6\%) and } \\
\text { S. thermosulfidooxidans (87.7\%) }\end{array}$ & {$[15]$} \\
\hline A. vulcanalis & 62 & A. acidocaldarius (97.8\%) & {$[22]$} \\
\hline
\end{tabular}

$\mathrm{G}+\mathrm{C}$ content in DNA is $48.6 \%$ to $63.0 \%$; it is $c a .62 \%$ for $A$. acidocaldarius, and $55 \%$ for the other species of Alicyclobacillus [13,31]. The content of G+C in A. acidoterrestris varies between $51.5 \%$ and 53.3\% depending on the strain, with the type strain, A. acidoterrestris DSM $3922^{\mathrm{T}}$, having a $\mathrm{G}+\mathrm{C}$ amount of $51.5 \%$ [20,31,32].

Guaiacol production is a common trait of the genus, although the amount of this compound is greatly variable [32].

Regarding sugar metabolism, there is acid but not gas production. Different species could be divided into different phenotypic groups, depending on sugar metabolism, although there is considerable variation within species [8,13]. As in Bacillus, the major respiratory lipoquinone of Alicyclobacillus is menaquinone-7 (MK-7) [13]. The branched respiratory chain of thermophilic bacilli is quite complex; MK-7 plays a fundamental role, as it is reduced by several dehydrogenases (malate, succinate, NADH). 
NADH dehydrogenase is of type II and does not translocate $\mathrm{H}^{+}$. Energy conservation occurs upon menaquinol oxidation by b6c1 complex and Cyt caa3. However, at high temperatures the concentration of dissolved oxygen quickly decreases, thus the Cyt pattern of cells suddenly changes [33].

Concerning the other metabolic traits, starch and gelatin hydrolysis, catalase and oxidase tests are generally species- and strain-dependent, as well resistance to $5 \% \mathrm{NaCl}$, nitrate reduction, catalase and oxidase activities [34].

Alicyclobacillus spp. were described as strictly aerobic microorganisms; however, some authors reported alicyclobacilli growth with $0.1 \%$ oxygen in the headspace [13]. Alicyclobacilli generally grow as planktonic and free cells, but they could also produce a biofilm under favorable conditions [34,35].

Alicyclobacillus spp. are the type organisms to study and characterize thermostable and non-conventional enzymes (endoglucanase, esterases, $\alpha$-galactosidase, arabinose isomerase, amylase and many others) [36-40]. These enzymes represent unique compounds due to their resistance to extreme conditions, as well as to their peculiarities in terms of structure [41], e.g.:

1. Lower number of charged residues. The $\alpha$-amylases extracted from Alicyclobacillus spp. contain ca. 30\% fewer charged residues than their closest relatives.

2. Acidic and basic residues. More basic residues are exposed on the surface, whereas the acidic groups are buried on the interior.

3. Salt bridges. Pechkova et al. [42] reported that an increase number of salt bridges results in greater compactness of the structure and thereby contributes to thermostability.

4. Cavities. Proteins from alicyclobacilli are more closely packed than the analogue molecules in mesophiles.

5. Proline. Thermostable proteins by alicyclobacilli show a higher content of proline and this amino acid is more common at the second position of the $\beta$-turns.

This is one last detail on a possible benefit and positive role of Alicyclobacillus spp. These microorganisms are generally labeled as spoilers or super-spoilers for acidic drinks; however, Yuan et al. [43] heat-inactivated alicyclobacilli cells and used them as adsorbing tools to remove/reduce patulin in apple juice. The removal rate was ca. $80 \%$ after $24 \mathrm{~h}$.

\section{Ecology of the Genus Alicyclobacillus, with a Special Focus on the Species A. acidoterrestris}

Spoilage of commercially available pasteurised fruit juice by Bacillus acidoterrestris was first reported in Germany in 1982 [44]. Several other cases of spoilage by similar bacteria occurred in Japan, Europe and the U.S.A. in 1990 [45,46]. Though spoilage by Alicyclobacillus spp. was previously regarded as sporadic, a 1998 survey by the National Food Processors Association (NEPA) in the USA reported that $35 \%$ of the fruit juice manufactures experienced spoilage caused by acidophilic spore-formers suspected to be $A$. acidoterrestris [3,8]. As a matter of fact, A. acidoterrestris caused spoilage of isotonic water and lemonade [47], carbonated fruit juice drinks [48], canned diced tomatoes [3] and fruit pulps, Australian shelf-stable iced tea containing berry juice [49], apple, pear, orange, peach, mango and white grape juices [8,30]. Alicyclobacillus strains were also isolated from orchard soil and a fruit concentrate production factory in South Africa; many strains were identified as A. acidoterrestris, but $A$. acidocaldarius was also recovered [50]. 
Fruit contaminated by soil during harvest or the use of unwashed or poorly washed raw fruits during processing are the most common sources of A. acidoterrestris [8]. Spores are also introduced into the manufacturing facilities by soil associated with employees. Water can also be a source of A. acidoterrestris spores; McIntyre et al. [51] isolated the same strain of Alicyclobacillus from spoiled juice and from water used by a processing facility. Recently, apple and pear flavourings have been reported as significant sources of $A$. acidoterrestris [52].

The fruit juice industry now acknowledges $A$. acidoterrestris as a major quality control target for thermal treatment efficacy [31,32,47,48,53]. It represents the greatest threat of spoilage in acidic foods because spores are able to germinate and grow at low $\mathrm{pH}$ [45].

Spoilage by Alicyclobacillus is difficult to detect because A. acidoterrestris does not produce gas during growth. The spoiled juice appears normal with little or no change in $\mathrm{pH}$. Occasionally, turbidity and/or white sediment may be formed at the bottom of the container. Members of Alicyclobacillus genus cause some clarified fruit juices to have a light sediment, cloudiness or haze [3].

However, the most common characteristic of Alicyclobacillus contamination is a "smoky", "medicinal”, "antiseptic" off-odour associated with guaiacol (2-methoxyphenol) [46,48], and other halophenols, including 2,6-dibromophenol and 2,6-dichlorophenol. The odour of the taint has also been described as smoky and pungent [54].

Guaiacol is a product of microbial metabolism in fruit juices and dairy foods. It is formed directly from vanillic acid by nonoxidative decarboxylation [8]. Many soil bacilli can decarboxylate vanillic acid to guaiacol. Vanillic acid is naturally derived from the plant polymer lignin and can be also introduced to the beverage as an ingredient. Alicyclobacillus spp. can also convert vanillic acid to vanillyl alcohol, catechol and methoxyhydroquinone [8]. Tyrosine is another possible precursor for guaiacol formation. Apple juice contains approximately $4.1 \mathrm{mg}$ tyrosine/ml juice and orange juice contains 3-13.5 mg tyrosine/ml [27]. Guaiacol production depends on the viable count of alicyclobacilli, strain, storage temperature, oxygen concentration in beverage, use of heat shock which encourages germination of the spores, and, finally, concentration of precursors to guaiacol, such as vanillin and tyrosine in the fruit juice $[8,48,55,56]$.

Fortunately, there is no evidence that $A$. acidoterrestris poses a human health risk. Neither the organism nor its metabolites have been associated with any form of illness and A. acidoterrestris is considered a non-pathogen [57]. However, in 2007 an endospore-forming organism was isolated from a blood sample from a 51-year-old woman on blood agar at $37^{\circ} \mathrm{C}$ [24]. There is no evidence that this strain was the causal agent of an infection. Based on 16S rRNA gene sequence similarity comparisons, the strain was grouped into the genus Alicyclobacillus, most closely related to the type strain of Alicyclobacillus pohliae (94.7\%), and was named A. consociatus. However, a reclassification was proposed for A. pohliae and A. consociatus as Effusibacillus pohliae and E. consociatus, respectively, according to phylogenetic and phenotypic analysis showing that the monophyly of the genus Alicyclobacillus had been lost [58].

A. acidoterrestris in fruit juice does not affect its $\mathrm{pH}$, thus it cannot enhance the growth of other pathogens such as Clostridium botulinum [59]. Detection, recovery and identification of Alicyclobacillus spp. in juices and other spoiled beverages is a great challenge, because the traditional plate-counting is a time-consuming methods; thus, some researchers have proposed some alternative approaches in the last three years. Table 3 offers a brief overview of the most important advances. 
Table 3. Overview of the most recent advances for the recovery and identification of Alicyclobacillus spp. (2014 and 2015).

\begin{tabular}{|c|c|c|}
\hline Method & Description & Reference \\
\hline $\begin{array}{l}\text { Lipase and esterase } \\
\text { fingerprints }\end{array}$ & Juice incubation at $45^{\circ} \mathrm{C}$ for $24 \mathrm{~h}$, cell harvesting and chromatography & {$[60]$} \\
\hline $\begin{array}{c}\text { Aptamer-based } \\
\text { enrichment 16S rDNA }\end{array}$ & $\begin{array}{l}\text { The method requires a preliminary enrichment step, so it can take up to } \\
1 \text { week. After a mechanical treatment, DNA was quantified through a } \\
\text { RT-PCR based approach }\end{array}$ & {$[61]$} \\
\hline $\begin{array}{c}\text { Immunomagnetic } \\
\text { separation RT-PCR }\end{array}$ & $\begin{array}{l}\text { Immunomagnetic separation was combined with RT-PCR, by using } \\
\text { two probes. The method is highly selective for A. acidoterrestris }\end{array}$ & {$[38]$} \\
\hline FIR & $\begin{array}{l}\text { Fourier transform } \\
\text { ed intra-red spectroscopy (1350-1700/cm), combined with multivariate } \\
\text { statistical analysis (Principal Component Analysis and Class Analogy), } \\
\text { allows the discrimination between Bacillus and Alicyclobacillus spp. }\end{array}$ & [62] \\
\hline $\begin{array}{c}\text { G-quadruplex } \\
\text { colorimetric method }\end{array}$ & $\begin{array}{l}\text { A. acidoterrestris was grown at } 45^{\circ} \mathrm{C} \text { in presence of vanillic acid; this } \\
\text { compound is easily converted to guaiacol and finally to tetraguaiacol } \\
\text { (amber-coloured). The reaction is catalysed by G-quadruplex } \\
\text { DNA-zyme }\end{array}$ & {$[63]$} \\
\hline DAS-ELISA & $\begin{array}{l}\text { DAS-ELISA (double antibodies sandwich ELISA) assay is based on } \\
\text { the two kinds of polyclonal antibodies from Japanese White rabbit. The } \\
\text { method shows high sensitivity and excellent agreement with isolation } \\
\text { by K medium }\end{array}$ & [64] \\
\hline
\end{tabular}

\section{Alternative Approaches to Mitigate Alicyclobacillus Species Associated with Food Spoilage}

Pasteurisation treatments on fruit juice are generally used to control bacterial contamination and increase shelf-life. The U.S. Food and Drug Administration requires all fruit juice sold in the United States to be either pasteurised or subjected to an equivalent process to achieve a mandated 5-log pathogen reduction in the juice [65].

Typically fruit juices are pasteurized through a flash treatment, which uses high temperature/short time to preserve the organoleptic and nutritional properties of the juice [66,67]; for example, fruit juice is heated to around $88-96^{\circ} \mathrm{C}$ for $30 \mathrm{~s}$ to $2 \mathrm{~min}$ and then rapidly cooled [68].

Unfortunately, A. acidoterrestris spores are able to survive thermal pasteurisation and hot-fill hold processes [9,45,69], but pasteurisation stimulates the germination of the spores. The design of pasteurization processes requires the evaluation of a $P$-value, which is the minimum heat required (time-temperature exposure to heat) to result in a product retaining quality during storage; the following details are required for a robust determination of $P$-value [70]:

- determination of $D$-value and z-value of $A$. acidoterrestris spores;

- potential for A. acidoterrestris spore growth during product storage for at least 1 month at 25 and $43^{\circ} \mathrm{C}$;

- quality during storage following pasteurization treatments of different severity.

However, the ability of $A$. acidoterrestris spores to survive thermal pasteurisation processes requires the design of alternative processing techniques to pasteurisation [9,69]. An interesting update and 
overview of the most important alternative approaches to control and/or reduce the contamination by Alicyclobacillus spp. is reported in the paper by Tianli et al. [71]. Figure 1 proposes a graphical abstract of the most used approaches.

The use of UV light as a germicidal tool is one such promising technology. Advantages associated with UV-C radiation used as a non-thermal method are that no known toxic or significant nontoxic by-products are formed during the treatment, and the treatment requires very little energy when compared to thermal pasteurisation. UV light was used as a suitable means to decrease alicyclobacilli contamination [72,73]; for example, Baysal and Ünlütürk [73] proposed this approach to reduce spore counts on the surface.

Another interesting physical intervention treatment is high-pressure homogenization (HPH). Its efficacy against cells and spores of $A$. acidoterrestris was reported by many authors [74,75]; Bevilacqua et al. [74] found that the antimicrobial effect was strain dependent and the spores were less sensible to HPH. The bactericidal activity of HPH could be due to the disruption of the cell wall and outer membrane [76]; pressures could induce a structural rearrangement of proteins, an increased exposure of their hydrophobic regions and the disruption of their supramolecular structure under pressure allowing the components to move freely and become independent of the original structure [76].

A pulsed electric field (PEF) is another non-thermal process, based on high-voltage short pulses delivered to the product placed between two electrodes. Electroporation is believed to be the principle of this method. Application of high-intensity pulsed electric fields destabilizes the microbial cell membrane and causes alterations in ion transport processes, which in turn results in cell damage and death [77]. The efficacy of PEF technology against spore-forming bacteria has been successfully demonstrated in fruit juices with minimal effects on freshness characteristics, such as color, $\mathrm{pH}$ value or flavour compounds [78,79].

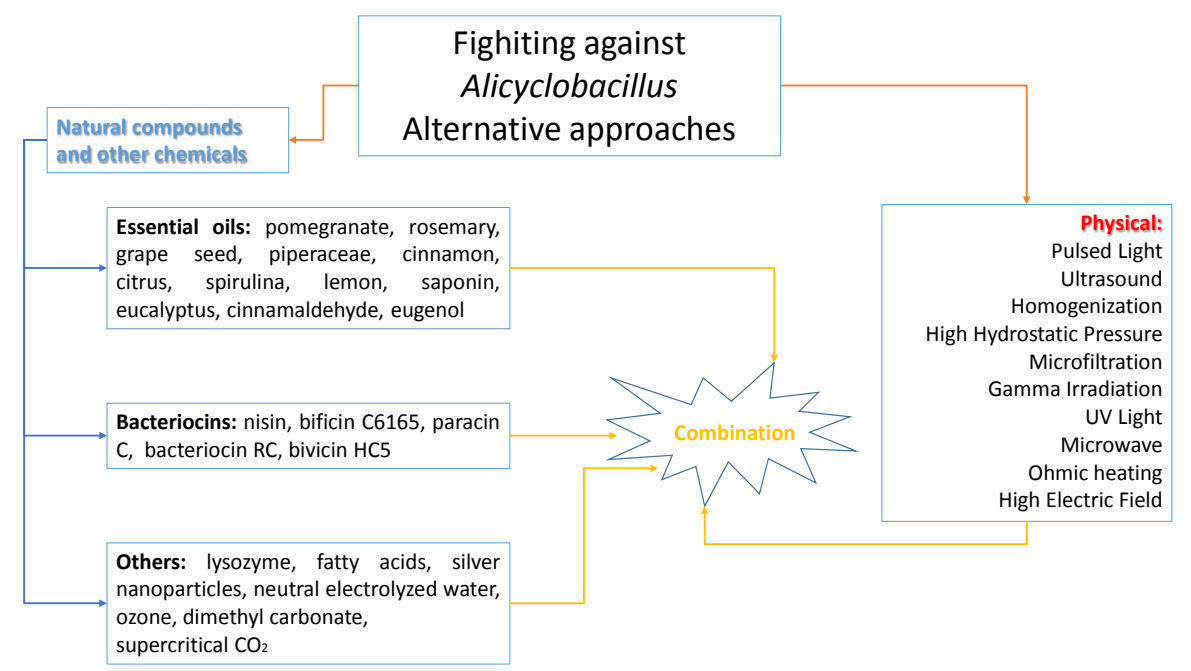

Figure 1. Alternative approaches to control Alicylobacillus spp. (overview from 2005 to 2015)

Ultrasound or ultrasonic waves (US) were defined as electromagnetic waves with frequency beyond $20 \mathrm{kHz}$. Ultrasound is able to disaggregate bacterial clusters and inactivate bacteria through the mechanical, physical, and chemical effects of acoustic cavitation [80]. Morales-de la Peña et al. [79] tested the effectiveness of treatment time and power of US on the inactivation rate of A. acidoterrestris. 
The inactivation mechanism of US might lie in intracellular cavitation, localized heating, cell membranes being thinner, and free radical production [81].

Another interesting approach might be also the use of chemical compounds such us nisin and other bacteriocins that exhibit bactericidal activity against certain bacteria [82], and A. acidoterrestris [32]. Nisin is currently the only bacteriocin approved for use in food by the FDA and the World Health Organization [83-85]. The bioactivity of nisin is influenced by $\mathrm{pH}$, water activity, content of solids, and the presence of other inhibitory factors [32,82,86,87]. However, some studies assert that the inhibitory action of nisin is lower in clear apple drink than in vitro studies, probably due to the ability of this compound to bind to some apple particles, although nisin would also be absorbed onto some particles in orange or mixed fruit drinks [82]. Nevertheless, nisin is heat stable and the beneficial effects of its inclusion prior to pasteurisation would be twofold: it would enhance the effect of the heat process, and residual nisin would prevent outgrowth of surviving spores.

In addition, some authors recommended the use of lysozyme for its bactericidal effectiveness, although the effect was strain-dependent [88].

Not least is the application of essential oils (EOs) against alicyclobacilli. The use of essential oils could be considered a new approach, as the stabilization of juices could be achieved through some natural molecules extracted from plants and fruits. Therefore, the consumer would not consider these antimicrobials as chemicals, but rather as natural ingredients of juices that might be added to commercial juices to improve the flavour of the products.

Cinnamaldeyde (100-500 ppm) was able to prevent spore germination of A. acidoterrestris for at least 13 days [89]; otherwise, eugenol acted as a strengthening element and, combined with cinnamaldeyde, reduced its amount in the system. Specifically, the experiments were performed in a commercial apple juice, thus highlighting that spore germination could be inhibited through the use of $80 \mathrm{ppm}$ of eugenol and $40 \mathrm{ppm}$ of cinnamaldehyde or alternatively through the combination of $40 \mathrm{ppm}$ of eugenol with 20 ppm of cinnamaldehyde [90].

Although many authors have previously reported the suitability of citrus extracts as natural preservatives for the inhibition of a wide range of microorganisms [91,92], to the best of our knowledge there are few data on the spores of $A$. acidoterrestris. The results of in vitro assay [93] confirmed that the bioactivity of citrus extracts was related to their concentrations with an effect called the "dose dependence effect” (DDE). Specifically, citrus and lemon extract showed MIC values (minimal inhibitory concentration) from 160 to 500 ppm against A. acidoterrestris spores.

Eucalyptus extracts and three compounds from Eucalyptus maculata were tested against spoiling microorganisms, and the effect on A. acidoterrestris was significant [94].

\section{Conclusions}

Cases of spoilage by Alicyclobacillus spp. of pasteurised fruit juice products have increased considerably in the last few years $[31,47,48,53,89]$. At present, the source of fruit juice contamination remains unclear. However, as members of the genus Alicyclobacillus are soil-borne organisms, it is thought that contaminated fresh fruit introduced during processing without proper cleaning leads to contamination and subsequent spoilage [45,69,95]. 
Standard pasteurization processes utilizing temperatures of 85 and $95{ }^{\circ} \mathrm{C}$, are commonly used to destroy pathogens such as Escherichia coli O157:H7 and Salmonella and are not effective against thermotolerant spore-forming spoilage bacteria [45]. Thermal processes able to affect Alicyclobacillus spores are not feasible as they are potentially harmful to product quality [3,96].

The ability of A. acidoterrestris spores to survive thermal pasteurisation and hotfill and hold processes used during fruit processing and fruit juice production requires the design of alternative techniques to reduce bacterial contamination [9,45,69]. The use of non-conventional approaches to control alicyclobacilli could be considered a promising method for the juice industry; however, literature data refer to laboratory media and to experiments performed at the lab scale. A future strategy would be the scaling up of lab techniques to the industry level, in order to pinpoint whether the designed approaches could be applied successfully in a real system.

\section{Author Contributions}

Emanuela Ciuffreda and Antonio Bevilacqua wrote the paper. Maria Rosaria Corbo and Milena Sinigaglia planned the review of the literature and revised the manuscript.

\section{Conflicts of Interest}

The authors declare no conflict of interest

\section{References}

1. Da Costa, M.S.; Rainey, F.A. Family II. Alicyclobacillaceae fam. nov. In: Bergey's Manual of Systematic Bacteriology, 2nd ed.; De Vos, P., Garrity, G., Jones, D., Krieg, N.R., Ludwig W., Rainey, F.A., Schleifer, K.H., Whitman, W.B., Eds.; Springer: New York, NY, USA, 2010; Volume 3, p. 229.

2. Wisotzkey, J.D.; Jurtshuk, P.; Fox, G.E.; Deinhart, G.; Poralla, K. Comparative sequence analyses on the 16S rRNA (rRNA) of Bacillus acidocaldarius, Bacillus acidoterrestris, and Bacillus cycloheptanicus and proposal for creation of a new genus, Alicyclobacillus gen. nov., Int. J. Syst. Bacteriol. 1992, 42, 263-269.

3. Walls, I.; Chuyate, R. Alicyclobacillus-Historical perspective and preliminary characterization study. Dairy Food Environ. Sanit. 1998, 18, 499-503.

4. Tourova, T.P.; Poltoraus, A.B.; Lebedeva, I.A.; Tsaplina, I.A.; Bogdanova, T.I.; Karavaiko, G.I. $16 \mathrm{~S}$ ribosomal RNA (rRNA) sequence analysis and phylogenetic position of Sulfobacillus thermosulfidooxidans. Syst. Appl. Microbiol. 1994, 17, 509-512.

5. Durand, P. Primary structure of the $16 \mathrm{~S}$ rRNA gene of Sulfobacillus thermosulfidooxidans by direct sequencing of PCR amplified gene and its similarity with that of other moderately thermophilic chemolithotrophic bacteria. Syst. Appl. Microbiol. 1996, 19, 360-364.

6. Oshima, M.; Ariga, T. $\omega$-Cyclohexyl fatty acids in acidophilic thermophilic bacteria. J. Biol. Chem. 1975, 250, 6963-6968.

7. Hippchen, B.; Roőll, A.; Poralla, K. Occurrence in soil of thermo-acidophilic bacilli possessing $\omega$-cyclohexane fatty acids and hopanoids. Arch. Microbiol. 1981, 129, 53-55. 
8. Chang, S.S.; Kang, D.H. Alicyclobacillus spp. in the fruit juice industry: History, characteristics, and current isolation/detection procedures. Crit. Rev. Microbiol. 2004, 30, 55-74.

9. Eiroa, M.N.U.; Junquera, V.C.A.; Schmidt, F.L. Alicyclobacillus in orange juice: Occurrence and heat resistance of spores. J. Food Protect. 1999, 62, 883-886.

10. Matsubara, H.; Goto, K.; Matsumura, T.; Mochida, K.; Iwaki, M.; Niwa, M.; Yamasoto, K. Alicyclobacillus acidiphilus sp. nov., a novel thermo-acidophilic, $\omega$-alicyclic fatty acid-containing bacterium isolated from acidic beverages. Int. J. Syst. Evol. Microbiol. 2002, 52, 1681-1685.

11. Guo, X.; You, X.Y.; Liu, L.J.; Zhang, J.Y.; Liu, S.J.; Jiang, C.Y. Alicyclobacillus aeris sp. nov., a novel ferrous- and sulphur-oxidizing bacterium isolated from a copper mine. Int. J. Syst. Evol. Microbiol. 2009, 59, 2415-2420.

12. Kusube, M.; Sugihara, A.; Moriwaki, Y.; Ueoka, T.; Shimane, Y.; Minegishi, H. Alicyclobacillus cellulosilyticus sp. nov., a thermophilic, cellulolytic bacterium isolated from steamed Japanese cedar chips from a lumbermill. Int. J. Syst. Evol. Microbiol. 2014, 64, 2257-2263.

13. Goto, K.; Mochida, K.; Kato, Y.; Asahara, M.; Fujita, R.; An, S.Y.; Kasai, H.; Yokota, A. Proposal of six species of moderately thermophilic, acidophilic, endospore-forming bacteria: Alicyclobacillus contaminans sp. nov., Alicyclobacillus fastidiosus sp. nov., Alicyclobacillus kakegawensis sp. nov., Alicyclobacillus macrosporangiidus sp. nov., Alicyclobacillus sacchari sp. nov. and Alicyclobacillus shizuokensis sp. nov. Int. J. Syst. Evol. Microbiol. 2007, 57, 1276-1285.

14. Nakano, C.; Takahashi, N.; Tanaka, N.; Okada, S. Alicyclobacillus dauci sp. nov., a slightly thermophilic, acidophilic bacterium isolated from a spoiled mixed vegetable and fruit juice product. Int. J. Syst. Evol. Microbiol. 2015, 65, 716-722.

15. Karavaiko, G.I.; Bogdanova, T.I.; Tourova, T.P.; Kondrat’eva, T.F.; Tsaplina, I.A.; Egorova, M.A.; Krasil'nikova, E.N.; Zakharchuk, L.M. Reclassification of "Sulfobacillus thermosulfidooxidans subsp. thermotolerans" strain K1 as Alicyclobacillus tolerans sp. nov. and Sulfobacillus disulfidooxidans Dufresne et al. 1996 as Alicyclobacillus disulfidooxidans comb. nov., and emended description of the genus Alicyclobacillus. Int. J. Syst. Evol. Microbiol. 2005, 55, 941-947.

16. Jiang, C.Y.; Liu, Y.; Liu, Y.Y.; You, X.Y.; Guo, X.; Liu, S.J. Alicyclobacillus ferrooxydans sp. nov., a ferrous-oxidizing bacterium from solfataric soil. Int. J. Syst. Evol. Microbiol. 2008, 58, 2898-2903.

17. Goto, K.; Matsubara, H.; Mochida, K.; Matsumura, T.; Hara, Y.; Niwa, M.; Yamasato, K. Alicyclobacillus herbarius sp. nov., a novel bacterium containing $\omega$-cycloheptane fatty acids, isolated from herbal tea. Int. J. Syst. Evol. Microbiol. 2002, 52, 109-113.

18. Albuquerque, L.; Rainey, F.A.; Chung, A.P.; Sunna, A.; Nobre, M.F.; Grote, R.; Antranikian, G.; da Costa, M.S. Alicyclobacillus hesperidum sp. nov. and a related genomic species from solfataric soils of São Miguel in the Azores. Int. J. Syst. Evol. Microbiol. 2000, 50, 451-457.

19. Goto, K.; Mochida, K.; Asahara, M.; Suzuki, M.; Kasai, H.; Yokota, A. Alicyclobacillus pomorum sp. nov., a novel thermo-acidophilic, endospore-forming bacterium that does not possess $\omega$-alicyclic fatty acids, and emended description of the genus Alicyclobacillus. Int. J. Syst. Evol. Microbiol. 2003, 53, 1537-1544.

20. Tsuruoka, N.; Isono, Y.; Shida, O.; Hemmi, H.; Nakayama, T.; Nishino, T. Alicyclobacillus sendaiensis sp. nov., a novel acidophilic, slightly thermophilic species isolated from soil in Sendai, Japan. Int. J. Syst. Evol. Microbiol. 2003, 53, 1081-1084. 
21. Kim, M.G.; Lee, J.C.; Park, D.J.; Li, W.J.; Kim, C.J. Alicyclobacillus tengchongensis sp. nov., a thermo-acidophilic bacterium isolated from hot spring soil. J. Microbiol. 2014, 52, 884-889.

22. Simbahan, J.; Drijber, R.; Blum, P. Alicyclobacillus vulcanalis sp. nov., a thermophilic, acidophilic bacterium isolated from Coso Hot Springs, California, USA. Int. J. Syst. Evol. Microbiol. 2004, 54, 1703-1707.

23. Deinhard, G.; Saar, J.; Krischke, W.; Poralla, K. Bacillus cycloheptanicus sp. nov., a new thermophile containing $\omega$-cycloheptane fatty acids. Syst. Appl. Microbiol. 1987, 10, 47-53.

24. Glaeser, S.P.; Falsen, E.; Martin, K.; Kämpfe, P. Alicyclobacillus consociatus sp. nov., isolated from a human clinical specimen. Int. J. Syst. Evol. Microbiol. 2013, 63, 3623-3627.

25. Poralla, K.; Kannenberg, E.; Blume, A. A glycolipid containing hopane isolated from the acidophilic, thermophilic Bacillus acidocaldarius, has a cholesterol-like function in membranes. FEBS Lett. 1980, 113, 107-110.

26. Kannenberg, E.; Blume, A.; Poralla, K. Properties of $\omega$-cyclohexane fatty acids in membranes. FEBS Lett. 1984, 172, 331-334.

27. Jensen, N. Alicyclobacillus-A new challenge for the food industry. Food Aust. 1999, 51, 33-36.

28. Suzuki, K.; Saito, K.; Kawaguchi, A.; Okuda, S.; Komagata, K. Occurrence of $\omega$-cyclohexyl fatty acids in Curtobacterium pusillum strains. J. Appl. Gen. 1981, 27, 261-266.

29. Kusano, K.; Yamada, H.; Niwa, M.; Yamasato, K. Propionibacterium cyclohexanicum sp. nov., a new acid-tolerant $\omega$-cyclohexyl fatty acid-containing propionibacterium isolated from spoiled orange juice. Int. J. Syst. Bacteriol. 1997, 47, 825-831.

30. Mavromatis, K.; Sikorski, J.; Lapidus, A.; del Rio, T.G.; Copeland, A.; Tice, H.; Cheng, J.F.; Lucas, S.; Chen, F.; Nolan, M.; et al. Complete genome sequence of Alicyclobacillus acidocaldarius type strain (104-IA $\left.{ }^{\mathrm{T}}\right)$. Stand. Genom. Sci. 2010, 2, 9-18.

31. Walker, M.; Phillips, C.A. Original article Alicyclobacillus acidoterrestris: An increasing threat to the fruit juice industry? Int. J. Food Sci. Technol. 2008, 43, 250-260.

32. Bevilacqua, A.; Sinigaglia, M.; Corbo, M.R. Alicyclobacillus acidoterrestris: New methods for inhibiting spore germination. Int. J. Food Microbiol. 2008, 125, 103-110.

33. Gennis, R.B. Respiration in archaea and bacteria: Diversity of prokaryotic electron transport carriers. In Advances in Photosynthesis and Respiration, 2nd ed.; Kluwer Academic Publishers: Dordrecht, The Netherlands, 2005; Volume 83, pp. 363-364.

34. Shemesh, M.; Pasvolsky, R.; Zakin, V. External $\mathrm{pH}$ is a cue for the behavioral switch that determines surface motility and biofilm formation of Alicyclobacillus acidoterrestris. J. Food Prot. 2014, 77, 1418-1423.

35. Dos Anjos, M.M.; Ruiz, S.P.; Nakamura, C.V.; de Abreu, F.; Alves, B. Resistance of Alicyclobacillus acidoterrestris spores and biofilm to industrial sanitizers. J. Food Prot. 2013, 76, 1408-1413.

36. Boyce, A.; Walsh, G. Characterisation of a novel thermostable endoglucanase from Alicyclobacillus vulcanalis of potential application in bioethanol production. Appl. Microbiol. Biotechnol. 2015, 99, 7515-7525.

37. Pennacchio, A.; Mandrich, L.; Manco, G.; Trincone, A. Enlarging the substrate portfolio of the thermophilic esterase EST2 from Alicyclobacillus acidocaldarius. Extremophiles 2015, 19, 1001-1011. 
38. Wang, Z.; Cai, R.; Yuan, Y.; Niu, C.; Hu, Z.; Yue, T. An immunomagnetic separation-real-time PCR system for the detection of Alicyclobacillus acidoterrestris in fruit products. Int. J. Food Microbiol. 2014, 175, 30-35.

39. Fan, C.; Liu, K.; Zhang, T.; Zhou, L.; Xue, D.; Jiang, B.; Mu, W. Biochemical characterization of a thermostable L-arabinose isomerase from a thermoacidophilic bacterium, Alicyclobacillus hesperidum URH17-3-68. J. Mol. Catal. Enzym. 2014, 102, 120-126.

40. Peng, H.; Wang, Y.; Zheng, Y.; Wang, M.; Xiao, Y.; Gao, Y. $\alpha$-Amylase (AmyP) of glycoside hydrolase subfamily GH13_37 is resistant to various toxic compounds. J. Mol. Catal. Enzym. 2013, 98, 114-118.

41. Bevilacqua, A.; Corbo, M.R. Characterization of a wild strain of Alicyclobacillus acidoterrestris: Heat resistance and implications for tomato juice. J. Food Sci. 2011, 76, M130-M136.

42. Pechkova, E.; Sivozhelezov, V.; Nicolini, C. Protein thermal stability: The role of protein structure and aqueous environment. Arch. Biochem. Biophys. 2007, 466, 40-48.

43. Yuan, Y.; Wang, X.; Hatab, S.; Wang, Z.; Wang, Y.; Luo, Y.; Yue, T. Patulin reduction in apple juice by inactivated Alicyclobacillus spp. Lett. Appl. Microbiol. 2014, 59, 604-609.

44. Cerny, G.; Hennlich, W.; Poralla, K. Fruchtsaftverderb durch Bacillen: Isolierung und charakterisierung des verderbserrengers. Z. Lebensm. Unters. Forsch. 1984, 179, 224-227. (In German)

45. Splittstoesser, D.F.; Churey, J.J.; Lee, Y. Growth characteristics of aciduric sporeforming Bacilli isolated from fruit juices. J. Food Prot. 1994, 57, 1080-1083.

46. Jensen, N.; Whitfield, F.B. Role of Alicyclobacillus acidoterrestris in the development of a disinfectant taint in shelf-stable fruit juice. Lett. Appl. Microbiol. 2003, 36, 9-14.

47. Yamazaki, K.; Teduka, H.; Shinano, H. Isolation and identification of Alicyclobacillus acidoterrestris from acidic beverages. Biosci. Biotechnol. Biochem. 1996, 60, 543-545.

48. Pettipher, G.L.; Osmundsen, M.E.; Murphy, J.M. Methods for the detection, enumeration and identification of Alicyclobacillus acidoterrestris and investigation of growth and production of taint in fruit juice-containing drinks. Lett. Appl. Microbiol. 1997, 24, 185-189.

49. Duong, H.A.; Jensen, N. Spoilage of iced tea by Alicyclobacillus. Food Aust. 2000, 52, 292.

50. Groenewald, W.G.; Gouws, P.A.; Witthuhn, R.C. Isolation, identification and typification of Alicyclobacillus acidoterrestris and Alicyclobacillus acidocaldarius strains from orchard soil and the fruit processing environment in South Africa. Food Microbiol. 2009, 26, 71-76.

51. McIntyre, S.; Ikawa, J.Y.; Parkinson, N.; Haglund, J.; Lee, J. Characteristics of an acidophilic Bacillus strain isolated from shelf-stable juices. J. Food Prot. 1995, 58, 319-321.

52. Oteiza, J.M.; Soto, S.; Alvarenga, V.O.; Sant’Ana, A.S.; Giannuzzi, L. Flavorings as new sources of contamination by deteriogenic Alicyclobacillus of fruit juices and beverages. Int. J. Food Microbiol. 2014, 172, 119-124.

53. Silva, F.V.M.; Gibbs, P. Target selection in designing pasteurization processes for shelf-stable high-acid fruit products. Crit. Rev. Food Sci. Nutr. 2004, 44, 353-360.

54. Siegmund, B.; Pöllinger-Zierler, B. Growth behavior of off-flavor-forming microorganisms in apple juice. J. Agric. Food Chem. 2007, 55, 6692-6699.

55. Bahçeci, K.S.; Gokmen, V.; Acar, J. Formation of guaiacol from vanillin by Alicyclobacillus acidoterrestris in apple juice: A model study. Eur. Food Res. Technol. 2005, 220, 196-199. 
56. Goto, A.; Nishibori, Y.; Wasada, K.; Furuhata, M.; Fukuyama, M.; Hara, Y. Identification of thermo-acidophilic bacteria isolated from the soil of several Japanese fruit orchards. Lett. Appl. Microbiol. 2008, 46, 289-294.

57. Borlinghaus, A.; Engel, R. Alicyclobacillus incidence in commercial apple juice concentrate (AJC) supplies-method development and validation. Fruit Process. 1997, 7, 262-266.

58. Watanabe, M.; Kojima, H.; Fukui M. Proposal of Effusibacillus lacus gen. nov., sp. nov., and reclassification of Alicyclobacillus pohliae as Effusibacillus pohliae comb. nov. and Alicyclobacillus consociatus as Effusibacillus consociatus comb. nov. Int. J. Syst. Evol. Microbiol. 2014, 64, 2770-2774.

59. Brown, K.L. Control of bacterial spores. Br. Med. Bull. 2000, 56, 158-171.

60. Cai, R.; Yuan, Y.; Wang, Z.; Wang, J.; Yue, T. Discrimination of Alicyclobacillus Strains by Lipase and Esterase Fingerprints. Food Anal. Method 2015, 1-6.

61. Hünniger, T.; Felbinger, C.; Wessels, H.; Mast, S.; Hoffmann, A.; Schefer, A.; Märtlbauer E.; Paschke-Kratzin, A.; Fischer, M. Food Targeting: A real-time PCR assay targeting 16S rDNA for direct quantification of Alicyclobacillus spp. spores after aptamer-based enrichment. J. Agric. Food Chem. 2015, 63, 4291-4296.

62. Al-Holy, M.A.; Lin, M.; Alhaj, O.A.; Abu-Goush, M.H. Discrimination between Bacillus and Alicyclobacillus isolates in apple juice by Fourier Transform Infrared Spectroscopy and multivariate analysis. J. Food Sci. 2015, 80, M399-M404.

63. Liu, T.; Zhang, X.; Zhu, W.; Liu, W.; Zhang, D.; Wang, J.A. G-quadruplex DNAzyme-based colorimetric method for facile detection of Alicyclobacillus acidoterrestris. Analyst 2014 139, 4315-4321.

64. Li, J.; Huang, R.; Xia, K.; Liu, L. Double antibodies sandwich enzyme-linked immunosorbent assay for the detection of Alicyclobacillus acidoterrestris in apple juice concentrate. Food Control 2014, 40, 172-176.

65. U.S. Food and Drug Administration. Irradiation in the production, processing and handling of food. Final rule. Fed. Regist. 2012, 77, 71312-71316.

66. Lado, B.H.; Yousef, A.E. Alternative food-preservation technologies: Efficacy and mechanisms. Microb. Infect. 2002, 4, 433-440.

67. Rivas, A.; Rodrigo, D.; Martínez, A.; Barbosa-Cánovas, G.V.; Rodrigo, M. Effect of PEF and heat pasteurization on the physical-chemical characteristics of blended orange and carrot-juice. LWT Food Sci. Technol. 2006, 39, 1163-1170.

68. Choi, L.H.; Nielsen, S.S. The effect of thermal and non-thermal processing methods on apple cider quality and consumer acceptability. J. Food Qual. 2005, 28, 13-29.

69. Orr, R.V.; Beuchat, L.R. Efficiency of disinfectants in killing spores of Alicyclobacillus acidoterrestris and performance of media for supporting colony development by survivors. J. Food Prot. 2002, 63, 1117-1122.

70. Silva, F.V.M.; Gibbs, P. Alicyclobacillus acidoterrestris spores in fruit products and design of pasteurization processes. Trends Food Sci. Technol. 2001, 12, 68-74.

71. Tianli, Y.; Jiangbo, Z.; Yahong, Y. Spoilage by Alicyclobacillus Bacteria in Juice and Beverage Products: Chemical, Physical, and Combined Control Methods. Compr. Rev. Food Sci. Food Saf. 2014, 13, 771-797. 
72. Zhao, D.; Barrientos, J.U.; Wang, Q.; Markland, S.M.; Churey, J.J.; Padilla-Zakour, O.I.; Worobo, R.W.; Kniel, K.E.; Moraru, C.I. Efficient Reduction of Pathogenic and Spoilage Microorganisms from Apple Cider by Combining Microfiltration with UV Treatment. J. Food Prot. 2015, 78, 716-722.

73. Baysal, A.H.D.; Ünlütürk, S. Short wave ultraviolet light (UVC) disinfection of surface-Inhibition of Alicyclobacillus acidoterrestris spores on agar medium. VTT Symp. 2008, 251, 92-93.

74. Bevilacqua, A.; Cibelli, F.; Corbo, M.R.; Sinigaglia, M. Effects of high pressur homogenization on the survival of Alicyclobacillus acidoterrestris spores in a laboratory medium. Lett. Appl. Microbiol. 2007, 45, 382-386.

75. Chen, W.; Harte, F.M.; Davidson, P.M.; Golden, D.A. Inactivation of Alicyclobacillus acidoterrestris using high pressure homogenization and dimethyl dicarbonate. J. Food Prot. 2013, 76, 1041-1045.

76. Vannini, L.; Lanciotti, R.; Baldi, D.; Guerzoni, M.E. Interactions between high pressure homogenization and antimicrobial activity of lysozyme and lactoperoxidase. Int. J. Food Microbiol. 2004, 94, 123-135.

77. Gongora-Nieto, M.M.; Sepùlveda, D.R.; Pedrow, P.; Barbarosa-Cànovas, G.V.; Swanson, B.G. Food Processing by Pulsed Electric Fields: Treatment Delivery, Inactivation Level and Regulatory Aspects. LWT-Food Sci. Technol. 2002, 35, 375-388.

78. Jin, Z.T.; Zhang, Q.H. Pulsed electric field inactivation of microorganisms and preservation of quality of cranberry juice. J. Food Process. Preserv. 1999, 23, 481-497.

79. Morales-de la Peña, M.; Salvia-Trujillo, L.; Rojas-Graü, M.A.; Martín-Belloso, O. Impact of high intensity pulsed electric field on antioxidant properties and quality parameters of a fruit juice-soymilk beverage in chilled storage. LWT_Food Sci. Technol. 2011, 43, 872-881.

80. Joyce, E.; Phull, S.S.; Lorimer, J.P.; Mason, T.J. The development and evaluation of ultrasound for the treatment of bacterial suspensions. A study of frequency, power and sonication time on cultured Bacillus species. Ultrason. Sonochem. 2003, 10, 315-318.

81. Piyasena, P.; Mohareb, E.; McKellar, R.C. Inactivation of microbes using ultrasound: A review. Int. J. Food Microbiol. 2003, 87, 207-216.

82. Yamazaki, K.; Murakami, M.; Kawai, Y.; Inoue, N.; Matsuda, T. Use of nisin for inhibition of Alicyclobacillus acidoterrestris in acidic drinks. Food Microbiol. 2000, 17, 315-320.

83. Pol, I.E.; Mastwijk, H.C.; Bartels, P.V.; Smid, E.J. Pulsed-electric field treatment enhances the bactericidal action of nisin against Bacillus cereus. Appl. Environ. Microbiol. 2000, 66, 428-430.

84. Cleveland, J.; Montville, T.J.; Nes, I.F.; Chikindas, M.L. Bacteriocins: Safe, natural antimicrobials for food preservation. Int. J. Food Microbiol. 2001, 71, 1-20.

85. Ross, A.I.V.; Griffiths, M.W.; Mittal, G.S.; Deeth, H.C. Combining non-thermal technologies to control foodborne microorganisms: A review. Int. J. Food Microbiol. 2003, 89, 125-138.

86. Komitopolou, E.; Boziaris, I.S.; Davies, E.A.; Delves-Broughton, J.; Adams, M.R. Alicyclobacillus acidoterrestris in fruit juices and its control by nisin. Int. J. Food Sci. Technol. 1999, 34, 81-85.

87. Pena, W.E.; de Massaguer, P.R. Microbial modeling of Alicyclobacillus acidoterrestris CRA 7152 growth in orange juice with nisin added. J. Food Prot. 2006, 69, 1904-1912.

88. Bevilacqua, A.; Ciuffreda, E.; Sinigaglia, M.; Corbo, M.R. Effects of lysozyme on Alicyclobacillus acidoterrestris under laboratory conditions. Int. J. Food Sci. Technol. 2014, 49, 224-229. 
89. Bevilacqua, A.; Corbo, M.R.; Sinigaglia, M. Inhibition of Alicyclobacillus acidoterrestris spores by natural compounds. Int. J. Food Sci. Technol. 2008, 43, 1271-1275.

90. Bevilacqua, A.; Corbo, M.R.; Sinigaglia M. Combining eugenol and cinnamaldehyde to control the growth of Alicyclobacillus acidoterrestris. Food Control 2010, 21, 172-177.

91. Fisher, K.; Phillips, C. Potential antimicrobial uses of essential oils in food: Is citrus the answer? Trends Food Sci. Technol. 2008, 19, 156-164.

92. Settanni, L.; Palazzolo, E.; Guarrasi, V.; Aleo, A.; Mammina, C.; Moschetti, G.; Germanà, M.A. Inhibition of foodborne pathogen bacteria by essential oils extracted from citrus fruits cultivated in sicily. Food Control 2012, 26, 326-330.

93. Bevilacqua, A.; Campaniello, D.; Speranza, B.; Sinigaglia, M.; Corbo, M.R. Control of Alicyclobacillus acidoterrestris in apple juice by citrus extracts and a mild heat-treatment. Food Control 2013, 31, 553-559.

94. Takahashi, T.; Kokubo, R.; Sakaino, M. Antimicrobial activities of eucalyptus leaf extracts and flavonoids from Eucalyptus maculata. Lett. Appl. Microbiol. 2004, 39, 60-64.

95. Pontius, A.J.; Rushing, J.E.; Foegeding, P.M. Heat resistance of Alicyclobacillus acidoterrestris spores as affected by various pH values and organic acids. J. Food Prot. 1998, 61, 41-46.

96. Palop, A.; Lvarez, I.; Raso, J.; Condon, S. Heat resistance of Alicyclobacillus acidocaldarius in water, various buffers, and orange juice. J. Food Prot. 2000, 63, 1377-1380.

(C) 2015 by the authors; licensee MDPI, Basel, Switzerland. This article is an open access article distributed under the terms and conditions of the Creative Commons Attribution license (http://creativecommons.org/licenses/by/4.0/). 